\title{
Police Policy in Kudus Resort Reveals Crime Conducted by Biological Mother to Biological Child
}

Tri Mulyono ${ }^{1}$

Abstract. Interest in this research are to understand policy of Kudus Police in uncovering criminal acts committed against the biological child's by biological mother. This research is empirical legal research, the research is based on analysis of law enforcement against criminal acts committed against the biological child's by biological mother, quantitatively analyzed inhibiting factors and solutions in law enforcement against criminal acts committed against the biological child's by biological mother

Penal mediation in criminal acts of persecution carried out due to several factors, among which are both economical in terms of both cost and time, factors fostering good relations because in general the party and the victims of family relations, neighbors, and friends.

The legal consequences of penal mediation in criminal acts of persecution that is if the penal mediation process is successful, the process of investigation in police Mangala stopped and will not proceed to court. Perpetrators and victims signed the act of peace. In addition, the offender must sign an agreement not to repeat the mistakes again.

A dilemma that is not easy in-swatch solution. On the one hand, domestic violence remains a force, an action which caused no casualties, the state has determined that the culprit may be a criminal. On the other hand, if the perpetrator in the crime, the family will bear the shame, domestic unity is threatened, there will be a long judicial process and air-late-late. If the perpetrator is a breadwinner in the household, the family will lose the main breadwinner.

Keywords: Crime; Biological Mother; Biological Children.

\section{Introduction}

Indonesia is a country that is great with so many problems that exist in it, from the maker of its laws are not pro-people, law enforcement officers who lack the discipline to run the rule, as well as the lack of numbers awareness of the importance of abiding by the community itself that causes many cases of crimes such as corruption, crimes against humanity, crimes involving minors and other highly developed in the community. With many such problems, the State is required to create a rule of law that can really hit the community not only provide a deterrent effect to the perpetrators of the crime, but how laws are made that can provide a sense of security and comfort for the public and can be hit directly into each individual communities that lead to real justice.

Today often found violations of the law occurring in society, particularly in the spotlight now is the cases involving children taken ages. Life between adults and children is formed in a pattern of relationships which controls or commonly called the relation of power. ${ }^{2}$

Deviations behavior or illegal acts committed by children caused by several factors, among others, the negative impact on the development of rapid development, the globalization in the field of communication and information, the advancement of science and technology

\footnotetext{
${ }^{1}$ Student Master of Law, Unissula, Email: tri.mulvono.tm35@gmail.com

${ }^{2}$ Melly Setyawati \& Supriyadi Widodo Eddyono, Perlindungan Anak Dalam Rancangan KUHP, Jakarta: ELSAM and Aliansi Nasional Reformasi KUHP, 2007, p. 3
} 
and changes in the style and way of life of older people who carry effect to the values and behavior of children, but it is less or not acquire affection, care, guidance and coaching in the development of attitudes, behavior, adjustment, as well as the supervision of a parent, guardian or foster parent will cause the child to easily dragged into the stream association and the unhealthy environment which may harm the development of his personality.

In facing and tackling the various actions and behavior of naughty child, the child needs to be considered top notch with all the typical characteristics and properties. Although children have been able to determine their own pace his actions by thinking, feeling and will, but circumstances can affect its behavior. Therefore, in dealing with problems naughty children, parents and the surrounding community should be responsible for the development, education and development of the child's behavior.

A high school (high school) initials PA, 17 (seventeen) years, reported Tukini, 52 (fifty-two) years, his own mother to the police. His mother reportedly because they do no violence to the child. ${ }^{3}$

Based on the problems described above, the authors are interested in doing research in the form of legal writing and discuss it in the form of a thesis titled "Police Policy In Kudus Resort Reveals Crime Conducted By Biological Mother To Biological Childconducted By Biological Mother To Biological Child".

\section{Research Methods}

This research approach is juridical-empirical approach. Yudiris approach is used to analyze the regulations related to the Criminal Law currently used empirical approach to legal analysis seen as patterned behavior of people in public life who constantly interact and relate in the community aspects. ${ }^{4}$

\section{Research Results and Discussion}

\subsection{Law Enforcement Against Criminal Acts Committed Against The Biological Child's By Biological Mother}

In Article 2 of Act No. 23 of 2004 mentioned the domestic sphere in this legislation include:

- Husband, wife and children of people who have a family relationship with the person as well as intent in a letter by blood, marriage, dairy, parenting, and representatives living in the household; and

- People working to assist the household and living in the household.

Police is a law enforcement intuition in the first instance to conduct investigations and inquiries in handling criminal cases before the case transferred to Attorney and the Court. In the development of the criminal system in Indonesia, the police complete a criminal case does not necessarily litigation path but the path of non-litigation approach to Restorative Justice. Litigation pathway used in the Police in handling criminal cases as a counterweight to the litigation path in terms of the losses and the side of justice in order to avoid new legal issues in the future. Basically completion persecution crime through penal mediation is not known by the Criminal Code, but over time and is based on fairness develop a situation to a certain conditionally so that cases do not always lead to the Court. Although in general the

\footnotetext{
${ }^{3}$ Prariset in the Kudus Police October 2, 2018

${ }^{4}$ Bambang Sungono, Metode Penelitian hukum, PT Raja Grafindo Persada, Jakarta, 2003, p. 23
} 
settlement of disputes outside the courts exist only in civil disputes, but in practice often criminal cases settled out of court with the discretion of law enforcement officers, peace mechanism, traditional institutions and others. Implications of practice for settling disputes out of court during this time there was no formal legal basis, so prevalent also occur a case has informally conducted a peaceful settlement through the mechanism of customary law, but still be processed according to court positive law. In the development of theoretical discourse and the development of criminal law reforms in many countries, there is a strong tendency to use criminal mediation as an alternative to the settlement of problems in the field of criminal law, this is known as penal mediation.

From the results of research conducted in Mr. AKP Mardi Susanto Police Chief in Police Sector Mejobo ${ }^{5}$. The completion of the crime of persecution sometimes be resolved by mediation, but not often. Approximately $50 \%$ per year, cases of criminal acts of persecution carried out either with penal mediation. Implementation of penal mediation in police Mejobo not necessarily the will of the investigator, but based on the litigants of both parties for the sake of social justice refers to the implementation of Act No. 2 of 2002 on the Indonesian National Police.

\subsection{Which Is A Barrier To Law Enforcement Against Criminal Acts Committed Against The Biological Child's By Biological Mother}

The acts of violence that occurred in the household has special qualities and special. The specialty of this action lies in the relationship between the perpetrator and the victim. In cases of criminal offenses other actors sometimes do not know the victim at all and often times do not have a relationship. But on domestic violence perpetrators and victims have a special relationship that the marriage relationship (husband and wife), blood relations (parents, children, niece) or relationship ties eg housemaids working and living in one house with the perpetrator.

Indonesian society is a society that prioritizes kinship. Domestic unity is important. If in the household there is a problem, as long as they can be resolved by amicable way, the path that will be chosen. Shame if known domestic ugliness and the devotion of a child to the biological mother. In a society has no rules were not simply be changed only with the advent of a law.

A dilemma that is not easy in-swatch solution. On the one hand, domestic violence remains a force, an action which caused no casualties, the state has determined that the culprit may be a criminal. On the other hand, if the perpetrator in the crime, the family will bear the shame, domestic unity is threatened, there will be a long judicial process and latest. If the perpetrator is a breadwinner in the household, the family will lose the main breadwinner.

\section{Closing}

\subsection{Conclution}

- Penal mediation in criminal acts of persecution carried out due to several factors, among which are both economical in terms of both cost and time, factors fostering good relations because in general the party and the victims of family relations, neighbors, and friends. In addition, consideration factors reasons stated suspect nor the victim (the

\footnotetext{
${ }^{5}$ Interview Mr. AKP Mardi Susanto Police Chief in Police Sector Mejobo Date December 16, 2018
} 
considerations put forward), if it is possible to be reconciled, legal consequences of mediation penal in criminal acts of persecution that is if the mediation process penal made, then the process of investigation in police Manggala stopped and will not proceed to court. Perpetrators and victims signed the act of peace. In addition, the offender must sign an agreement not to repeat the mistakes again.

- A dilemma that is not easy in-swatch solution. On the one hand, domestic violence remains a force, an action which caused no casualties, the state has determined that the culprit may be a criminal. On the other hand, if the perpetrator in the crime, the family will bear the shame, domestic unity is threatened, there will be a long judicial process and latest. If the perpetrator is a breadwinner in the household, the family will lose the main breadwinner.

- Considering the crime prevention solutions through non-penal lines are more precautions for the occurrence, the main goal is to deal with the factors conducive penye chapter of the crime. Factors conducive among others centered on the problems or conditions so-unlucky that directly or indirectly may result from the standpoint of political or criminal fertilize the crime. Thus the macro and global, the efforts of nonpenal key and strategic position of the overall political effort criminal.

\subsection{Suggestion}

- The government needs to make legislation and restrictions for criminal acts that can be resolved through mediation Police penal level.

- The government needs to make legislation on penal procedure of mediation in order to practice the application level, the Police field a clear legal basis.

- Practice settlement through mediation penal criminal acts by promoting the process of deliberation and consensus to achieve the end result that gives a sense of justice between victims and perpetrators of criminal acts, is expected to be realized in the Islamic law based on the Qur'an and Sunnah in the future.

\section{Bibliography}

[1] Andi Hamzah, 2001, Bunga Rampai Hukum Pidana dan Acara Pidana, Jakarta, Ghalia Indonesia

[2] Bambang Purnomo dan Arun Sakidjo, 2003, Seri Hukum Pidana 1, Ghalia Indonesia, Jakarta.

[3] Bambang Sungono, 2003, Metode Penelitian hukum, PT Raja Grafindo Persada, Jakarta.

[4] Carl Joachim Friedrich, 2004. "Filsafat Hukum Perspektif Historis, Nuansa dan Nusamedia. Bandung

[5] Boediono, 1990, Ekonomi Moneter, BPFE, Yogyakarta

[6] Dellyana,Shant, 1988, Konsep Penegakan Hukum. Liberty Yogyakarta

[7] Hans Kelsen, 2011. "General Theory of Law and State", diterjemahkan oleh Rasisul Muttaqien, Bandung, Nusa Media

[8] Lawrence M. Friedman, Sistem Hukum: Perspektif Ilmu Sosial, Diterjemahkan oleh M. Khozim, Nusa Media, Bandung

[9] L. J. Van Apeldoorn, 1996, "Pengantar Ilmu Hukum”, Pradnya Paramita, Jakarta. 